ISSN 1392-3196 / e-ISSN 2335-8947

Zemdirbyste-Agriculture, vol. 103, No. 3 (2016), p. 327-334

DOI $10.13080 /$ z-a.2016.103.042

\title{
Measurements and modelling of wind erosion rate in different tillage practices using a portable wind erosion tunnel
}

\author{
Kazım ÇARMAN ${ }^{1}$, Tamer MARAKOĞLU ${ }^{1}$, Alper TANER ${ }^{2}$, Fariz MIKAILSOY ${ }^{3}$ \\ ${ }^{1}$ University of Selcuk \\ Alaeddin Keykubat Campus, 42075 Selçuklu, Konya, Turkey \\ E-mail: marakoglu@selcuk.edu.tr \\ ${ }^{2}$ University of Ondokuz Mayis \\ 55139 Atakum, Samsun, Turkey \\ ${ }^{3}$ University of Iğdır \\ Suveren Campus, 76000 Iğdır, Turkey
}

\begin{abstract}
Artificial intelligence systems are widely accepted as a technology providing an alternative method to solve complex and ill-defined problems. Artificial neural network (ANN) is a technique with a flexible mathematical structure, which is capable of identifying a complex nonlinear relationship between the input and output data. The objective of this study was to investigate the relationship between dust concentration and wind erosion rate, and to illustrate how ANN might play an important role in the prediction of wind erosion rate. Data were recorded via field experiments by using a portable field wind tunnel. The experiments were carried out for eight different tillage applications that include the conventional, six different reduced tillage and the direct seeding practices. Particulate matter (PM) concentration generally decreased with a decrease in number or intensity of tillage operations. Direct seeding resulted in the lowest $\mathrm{PM}_{10}$ concentration. After tillage applications, wind erosion rate varied between 113 and $1365 \mathrm{~g} \mathrm{~m}^{-2} \mathrm{~h}^{-1}$. Results showed that wind erosion rate was lower in direct seeding than in conventional and reduced tillage applications. In this paper, a sophisticated intelligent model, based on a 1-(8-5)-1 ANN model with a back-propagation learning algorithm, was developed to predict the changes in the wind erosion rate due to dust concentration occurring during tillage. In addition, the prediction of the model was made according to traditional methods of wind erosion rate by using the programme Statistica, version 5. The verification of the proposed model was carried out by applying various numerical error criteria. The ANN model consistently provided better predictions compared with the nonlinear regression-based model. The relative error of the predicted values was found to be less than the acceptable limits $(10 \%)$. Based on the results of this study, ANN appears to be a promising technique for predicting wind erosion rate.
\end{abstract}

Key words: artificial neural network, conservation tillage, dust concentration, soil erodibility by wind.

\section{Introduction}

In Turkey, soil erosion is a major problem for agricultural sustainability. The loss of soil from the current and past management practices is a major cause of low crop productivity and inefficient use of cropping inputs, and it can also have significant off-farm adverse impacts on the environment. The soil erosion takes place by the three main processes: wind, water, and tillage erosion. The combined effect of the wind, water, and tillage erosion is a more serious problem than individual erosion processes. Tillage erosion is a problem persisting since the dawn of cultivation. The problem has been intensified with increased tillage speed, depth, and size of tillage tools and with the tillage of steeper and more undulating lands. The tillage erosion has often been described in the qualitative rather than the quantitative terms. The evidence of the mass down slope movement of the soil by tillage has been known for years.
As compared with the uncultivated soil, the cultivated soil undergoes more serious wind erosion. As the soil surface roughness produced by tillage is an important factor that significantly affects the wind erosion on the cultivated soil (Logsdon, 2013), alternative cropping systems that optimize the soil surface roughness to reduce the wind erosion were determined.

In the semiarid cultivated areas where the conventional tillage continues to be used, tillage ridges and soil cloddiness are the only soil roughness elements that help to reduce the soil erosion by wind because the vegetation cover is limited (Blanco-Canqui, Lal, 2010; Labiadh et al., 2013; Meijer et al., 2013). Lopez et al. (2000) found lower soil erodibility by wind under the reduced tillage. This tillage system can be considered as a suitable soil management practice to prevent the wind erosion during the fallow period in the semiarid drylands of the Central Aragón in Northeastern Spain. 
Liu et al. (2006) used the ridge tillage as an alternative method for the control of wind erosion on the croplands during the fallow period in the arid and semiarid regions. Using the wind tunnel experiments, the wind erosion rates under the simulated conditions of the ridge tillage and the flat tillage were studied for 15,10 , 10,5 and $3 \mathrm{~min}$ exposures at the wind velocities of 8 , $10,15,20$ and $24 \mathrm{~m} \mathrm{~s}^{-1}$, respectively. The results of the soil tested indicate that the mean rate of the wind erosion under the flat tillage was $129.89 \mathrm{~g} \mathrm{~m}^{-2} \mathrm{~min}^{-1}$, while that under the ridge tillage was $20-60 \%$ less.

The sediment and particulate matter (PM) losses measured under high winds were compared for three summer fallow management methods in the fallow phase of a winter wheat - summer fallow cropping system rotation in the Horse Heaven Hills of the south-central Washington. The sediment and $\mathrm{PM}_{10}$ (particulate matter $\leq 10 \mathrm{~mm}$ in aerodynamic diameter) losses were increased by both the primary spring tillage and sowing operations. The conventional tillage fallow with a tandem disk indicated to have the highest sediment and $\mathrm{PM}_{10}$ losses, while no-tillage fallow indicated to have the lowest losses (Singh et al., 2012).

Similar soil categories with the same textures can create different dust emissions. Unlike in the $\mathrm{PM}_{10}$ emission, the soil organic matter can induce changes in the overall size and aggregate stability. Soil moisture is an important factor in the emission of dust control. Thus, the effect of the moisture depends on the change in the soil texture. Aimar et al. (2012) found that moisture effects on $\mathrm{PM}_{10}$ emissions decreased in a logarithmic way when organic matter contents increased in relation to silt contents. In general, maximum $\mathrm{PM}_{10}$ emissions were higher in soils with high silt contents, excepting for one of them developed on lake sediments which, even when silt contents were high, it presented low $\mathrm{PM}_{10}$ emissions as a consequence of its high organic matter contents.

Artificial intelligence consists of two major branches, namely, the study of artificial neural networks (ANNs) and expert systems. ANN models may be used as an alternative method for the analysis and predictions of the engineering problems. Recently, a great interest has been developed in ANN models. Neuron is known as the fundamental processing element of a neural network. ANN models can be successfully applied to solve the complex problems in various fields of mathematics, engineering, agriculture, and many others. Today, ANN models can be aimed to solve problems that are difficult for the conventional computers or human beings. In addition, ANN models overcome the limitations of the conventional approach by extracting the desired information directly from the data (Samarasinghe, 2007; Martí et al., 2013).

ANN is emerging as a common method for modelling the complex input-output data. The structure of ANN consists of a number of interconnected units (neurons). Each neuron in the network is able to receive the input signals, to process them, and to send an output signal. Moreover, each neuron is connected with at least one other neuron, and each connection is represented by a real number, which is called weight. The weights are adjusted so that the network attempts to produce the desired output. A typical ANN is structured using three neural layers: an input layer, a hidden layer (sometimes more than one layer is necessary), and an output layer. Information flows from the input layer to the output layer through the hidden layers (Martí et al., 2013; Ekinci et al., 2015).

In Middle Anatolia in Turkey, erosion is still persistent due to irrational soil tillage and agricultural applications. The wind erosion and dust storms have emerged as the main daily environmental problems for the people living in the region. In this study, the relationship between the soil erosion rate and the dust concentration occurring during tillage was examined for the first time. Some published papers (Liu et al., 2006; Mendez, Buschiazzo, 2010; Logsdon, 2013; Zamani, Mahmoodabadi, 2013) provided the method of determining the wind erosion in the soil tillage. However, no paper provided the method of modelling the soil erosion rate in agricultural production (especially by using the dust concentration). Therefore, the objective of this study was to determine and model the soil erosion rate in agricultural production based on eight different tillage applications.

\section{Material and methods}

The present study was conducted in the experimental fields of Karaaslan Soil, Water and Combating Desertification Research Station in Konya, Turkey (E 32 $31^{\prime}$, N $37^{\circ} 52^{\prime}, 1050 \mathrm{~m}$ a.s.l.) during the years 2012-2013 (the first year) and 2013-2014 (the second year). Konya is considered a semiarid region. The soil texture of the experimental fields covering stubble was clayey-loamy according to the FAO soil classification. The some properties of soil and long-term weather data at the experimental station were given in Tables 1 and 2 . The average temperature and precipitation of the site during the vegetation period were $10.43^{\circ} \mathrm{C}$ and $323 \mathrm{~mm}$ for the first year $11.19^{\circ} \mathrm{C}$ and $301.2 \mathrm{~mm}$ for the second year, respectively. The average temperature and precipitation values in both production seasons were very close to the average for many years.

Table 1. The some properties of soil at the experimental station located in Karaaslan, Konya, Turkey

\begin{tabular}{|c|c|c|c|}
\hline & & $\begin{array}{c}2012-2013 \\
\text { year }\end{array}$ & $\begin{array}{c}\text { 2013-2014 } \\
\text { year }\end{array}$ \\
\hline \multirow{3}{*}{ Texture $\%$} & sand & 36.88 & 36.88 \\
\hline & clay & 42.94 & 42.94 \\
\hline & silt & 20.18 & 20.18 \\
\hline \multicolumn{2}{|c|}{ Moisture content $\%$} & 15.9 & 18.46 \\
\hline \multicolumn{2}{|c|}{ Organic matter $\%$} & 0.76 & 1.21 \\
\hline \multicolumn{2}{|c|}{ Penetration resistance $\mathrm{MPa}$} & 2.09 & 2.16 \\
\hline \multicolumn{2}{|c|}{ Surface roughness $\%$} & 4.56 & 10.5 \\
\hline \multicolumn{2}{|c|}{ Shear stress $\mathrm{N} \mathrm{cm}^{-2}$} & 2.23 & 2.06 \\
\hline \multicolumn{2}{|c|}{ Stubble amount $\mathrm{g} \mathrm{m}^{-2}$} & 144 & 252 \\
\hline
\end{tabular}


Table 2. Long-term (64 years) weather data at the experimental station located in Karaaslan, Konya, Turkey

\begin{tabular}{lc}
\hline \multicolumn{2}{c}{ Weather parameters } \\
\hline Minimum air temperature ${ }^{\circ} \mathrm{C}$ & -26.5 \\
Maximum air temperature ${ }^{\circ} \mathrm{C}$ & 40.6 \\
Average air temperature ${ }^{\circ} \mathrm{C}$ & 11.6 \\
Minimum precipitation $\mathrm{mm}$ & 171.6 \\
Maximum precipitation $\mathrm{mm}$ & 413 \\
Average precipitation $\mathrm{mm}$ & 319.7 \\
Maximum wind speed $\mathrm{m} \mathrm{s}^{-1}$ & 13.2 \\
Average wind speed $\mathrm{m} \mathrm{s}^{-1}$ & 2.2 \\
\hline
\end{tabular}

The experiments were carried out for eight different tillage applications (Table 3). Soil tillage applications were performed on October 15-16, 2012 for the first year and on October 21-22, 2013 for the second year. The design of the experiment was a randomized complete block with three replications. Individual plot size was $100 \times 10 \mathrm{~m}$.

Table 3. Tillage treatments

\begin{tabular}{ll}
\hline $\begin{array}{l}\text { Conventional tillage } \\
\text { (T1) }\end{array}$ & $\begin{array}{l}\text { mouldboard plough + cultivator-float } \\
\text { (twice) }\end{array}$ \\
Reduced tillage (T2) & chisel plough-float \\
Reduced tillage (T3) & winged chisel plough-float \\
Reduced tillage (T4) & $\begin{array}{l}\text { alternative moving rototiller-float } \\
\text { direct seeding } \\
\text { No tillage (T5) }\end{array}$ \\
Reduced tillage (T6) & $\begin{array}{l}\text { (L-type foot)-float } \\
\text { horizontal shaft rototiller } \\
\text { (I-type foot)-float }\end{array}$ \\
Reduced tillage (T7) & vertical shaft rototiller-float \\
\hline
\end{tabular}

In order to measure the wind erosion rate, the experiments were carried out using a portable field wind tunnel. The system consisted of three parts: a wind generator for producing different wind speeds, a working section with a cross-sectional area of $1 \times 1 \mathrm{~m}$, and a sediment collector. Moreover, it was a suctiontype tunnel with a $9 \times 1 \mathrm{~m}$ working section that was placed on the field surface of each individual plot. The prepared surface (after tillage) was allowed to dry for at least $2 \mathrm{~h}$ prior to testing. Experiments were conducted for $30 \mathrm{~min}$ at a wind velocity of $13 \mathrm{~m} \mathrm{~s}^{-1}$. Sediment fluxes were measured with BEST cyclone-type dust (sediment) catchers (Basaran et al., 2011) that were placed on a vertical post at heights of $0.07,0.24,0.45,0.70$ and $0.95 \mathrm{~m}$ (Maurer et al., 2006). After each run, the sediment was collected; oven dried at $105^{\circ} \mathrm{C}$, and weighed on a balance. To obtain the wind erosion rate $\left(\mathrm{g} \mathrm{m}^{-2} \mathrm{~h}^{-1}\right)$, the mass of the sediment $(\mathrm{g})$ was divided by the test area $\left(\mathrm{m}^{2}\right)$ and event duration (h) (Zamani, Mahmoodabadi, 2013). Measurements were made once after one day from tillage in both years.

For the measurement of the dust concentration, the portable dust MIE pDR-1500 (Thermo Fisher Scientific Inc., USA) measurement devices were used in particulate matter $\left(\mathrm{PM}_{10}-\right.$ particulate matter $\leq 10 \mathrm{~mm}$ in aerodynamic diameter). The dust concentration measurement range of the device was $0.001-400 \mathrm{mg} \mathrm{m}^{-3}$ and the range of the particle size was $0.1-10 \mu \mathrm{m}$. The measurements were carried out by connecting special apparatus at $1 \mathrm{~m}$ height and at a distance of $1 \mathrm{~m}$ from the rear part of the equipment used in the soil tillage.

In this study, artificial neural network (ANN) techniques were applied to estimate the wind erosion rate. In the ANN model, the dust concentration $(x)$ was used as an input parameter and the wind erosion rate $(y)$ was used as an output parameter. In addition, a total of 16 datasets consisting of 11 datasets for training and 5 datasets for the test were used in this study. The input and output data used were normalized between 0 and 1 (Ağın, Taner, 2015). For normalization, the following equation was used:

$$
y_{\text {nor }}=\frac{y-y_{\min }}{y_{\max }-y_{\min }}
$$

To obtain the real values from the normalized values, the " $y$ " value was calculated using the same equation.

In the ANN model, the structure of the network was designed in the form of 1-(8-5)-1, which consisted one input layer, two hidden layers, and one output layer; and the number of neurons in the hidden layer were 8-5 (Fig. 1).

In the ANN model, the Feed Forward Back Propagation (BP) and Multilayer Perceptron (MP) network structures were used. In this network, the BP algorithm is the most popular and commonly used one. It minimizes the total errors by varying the weights in order to improve the performance of the network. Another aspect in ANN is training algorithm. There are numerous algorithms for training neural network models. In this study, the Levenberge-Marquardt (LM), the gradient descent (GD) algorithm and the gradient descent algorithm with momentum (GDM) methods has been used for training (Naghsh-Nilchi, Aghashahi, 2009). The training of the network was continued until the test error reached the determined tolerance value. After the successful training of the network, the network was tested by the test data (Ekinci et al., 2015). In addition, the prediction of the model was made according to the traditional methods of the wind erosion rate $(\tilde{y})$ by using the programme Statistica, version 5 . The dust concentration $(x)$ was used as a variable to obtain the predicted values. The coefficient of determination of regression models was predicted as $92.64 \%$. The nonlinear regression model developed is given as follows:

$$
\tilde{y}_{x}=\exp \left(a+b x-\frac{c}{x}\right)=\exp \left(7.183+0.0017 x-\frac{42.473}{x}\right)
$$

The predictive ability of the developed system was examined according to the mathematical and statistical methods. In order to determine the performances of the results, $\varepsilon$, RMSE and $R^{2}$ values that are considered to be the principal accuracy measures and that are based on the concept of the mean error and are commonly used were 


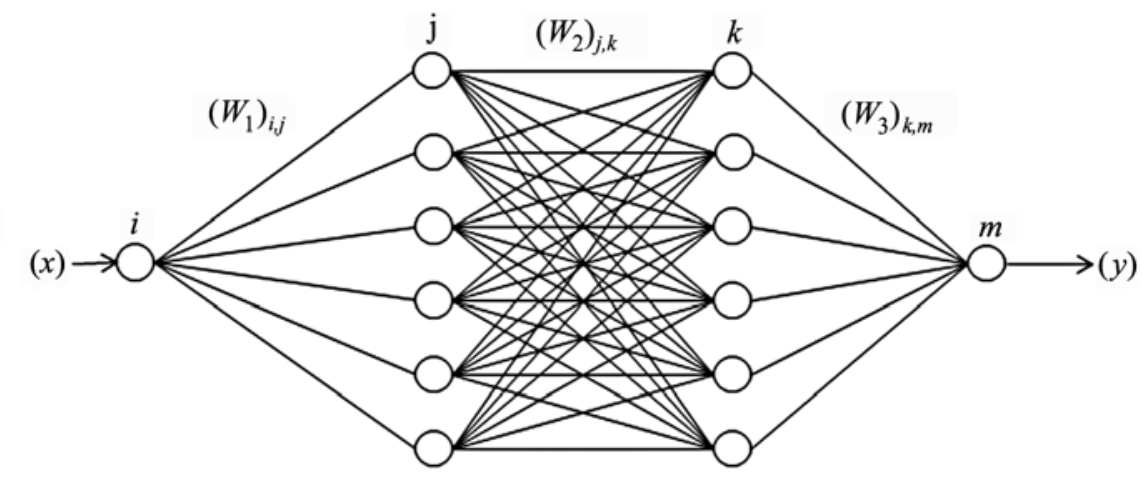

Input layer

Hidden layer

Output layer

Figure 1. The network structure of the artificial neural network (ANN) model

calculated using the following equations (Kashaninejad et al., 2009; Çarman, Taner, 2012):

$$
\begin{aligned}
& R M S E=\left(\frac{1}{n} \sum_{i=1}^{n}\left(y_{i}-\tilde{y}_{i}\right)^{2}\right)^{1 / 2} \\
& R^{2}=1-\left(\sum_{i=1}^{n}\left(y_{i}-\tilde{y}_{i}\right)^{2}\right) /\left(\sum_{i=1}^{n}\left(y_{i}-\bar{y}\right)^{2}\right) \\
& \varepsilon=\frac{100}{n} \sum_{i=1}^{n} \frac{y_{i}-\tilde{y}_{i}}{y_{i}}
\end{aligned}
$$

where RMSE is the root-mean-square error, $R^{2}$ - the coefficient of determination, $\varepsilon$ - the relative error of the system, $n$ - the number of data, $y_{i}$ - the measured value, $\tilde{y}_{i}-$ the predicted value and $\bar{y}-$ the mean value.

\section{Results and discussion}

The dust concentration values varied between 17.73 and $143.45 \mathrm{mg} \mathrm{m}^{-3}$ depending on eight different tillage applications (Fig. 2). The average dust concentration was the lowest in direct seeding (T5) method with the value of $21.52 \mathrm{mg} \mathrm{m}^{-3}$ while the highest in horizontal axis of the rototiller (L-type foot)-float (T6) method with the value of $117.52 \mathrm{mg} \mathrm{m}^{-3}$. Similar results were also obtained in reduced tillage applications driven power take-off. A large activity of soil fragmenting on the horizontal shaft rototiller applications caused the achievement of values of about more than $10 \%$ of the dust concentration compared with the vertical shaft rototiller. In the second year of the trials, an increase of about $16 \%$ in the soil moisture resulted in a decrease of $32.2 \%$ in the dust concentration. When the chisel plough (T2) system was compared to the other reduced tillage systems, it was found that on average less than $57.8 \%$ of dust concentration was realized. When the winged chisel plough (T3) was compared with the chisel plow (T2), depending on the increasing deformation zone of the soil, the average dust concentration value of the winged chisel plough was found to be more than $109 \%$.

Sharratt and Feng (2009) compared soil loss and $\mathrm{PM}_{10}$ concentration from adjacent fields, managed using conventional tillage (spring disk followed by rodweeding) and undercutter tillage (spring undercut followed by rodweeding) during the summer fallow phase of a wheat-fallow in the Columbia Plateau. They found that undercutter tillage reduced soil loss and $\mathrm{PM}_{10}$

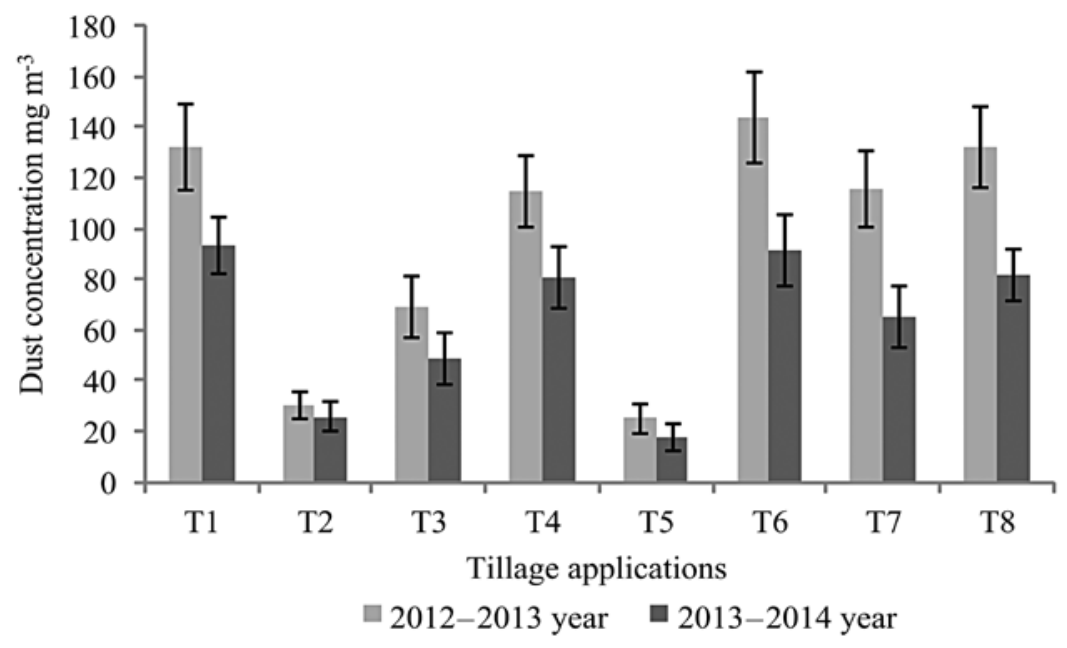

T1 - conventional tillage, T2 - chisel plough-float, T3 - winged chisel plough-float, T4 - alternative moving rototiller-float, T5 direct seeding, T6 - horizontal shaft rototiller (L-type foot)-float, T7 - horizontal shaft rototiller (I-type foot)-float, T8 - vertical shaft rototiller-float

Figure 2. The effect on dust concentration of different tillage applications 
concentration by $15-75 \%$ across the high wind events as compared to conventional tillage. Sharratt et al. (2010) examined possible alternatives to conventional tillage for reducing the emission of windblown $\mathrm{PM}_{10}$ during summer fallow. Soil was subject to seven (conventional tillage), five (reduced tillage), three (delayed-minimum tillage) and direct seeding operations between harvest and seeding. $\mathrm{PM}_{10}$ concentration generally decreased with a decrease in number or intensity of tillage operations. Direct seeding resulted in the lowest $\mathrm{PM}_{10}$ concentration after most tillage operations. $\mathrm{PM}_{10}$ concentration was typically lower for reduced and delayed-minimum tillage than for conventional tillage. Wang et al. (2010) carried out the field experiments to measure dust concentration from rolling, disking, listing, planting, and harvesting cotton in 2005. They found that dust concentrations were $12.1 \mathrm{mg} \mathrm{m}^{-3}$ for rolling, $44.8 \mathrm{mg} \mathrm{m}^{-3}$ for disking, 210.7 $\mathrm{mg} \mathrm{m}^{-3}$ for listing, $176.7 \mathrm{mg} \mathrm{m}^{-3}$ for planting, and 10.4 $\mathrm{mg} \mathrm{m}^{-3}$ for harvesting. The values shown in Figure 1 are lower than those reported by them.

The wind erosion rates varied between 113 and $1365 \mathrm{~g} \mathrm{~m}^{-2} \mathrm{~h}^{-1}$ depending on eight different tillage applications (Fig. 3). On average, the lowest value of the wind erosion rate from a tillage was obtained in direct seeding (T5) application and the highest value was obtained in the application of the horizontal shaft of the rototiller (L-type foot)-float (T6). The analysis of variance performed on wind erosion values showed that the difference between soil tillage applications were significant $(P<0.01)$. The difference between the conventional tillage (T1), alternative moving rototiller (T4), horizontal shaft rototiller (I-type foot) (T7) and vertical shaft rototiller (T8) applications were not significant. A large activity of soil fragmenting on the horizontal shaft rototiller caused the achievement of values of about more than $15.6 \%$ of the wind erosion rate compared with the vertical shaft rototiller. In the second year of trials, an increase of about $16 \%$ in the soil moisture resulted in a decrease of $17.8 \%$ in the wind erosion rate. When the chisel plough (T2) system compared to the other reduced tillage systems, it was found that on average less than $50.5 \%$ of wind erosion rates were realized. When the winged chisel plough (T3) was compared with the chisel plough (T2), depending on the increasing deformation zone of the soil, the average wind erosion rate value of the winged chisel plough was found to be more than $135.4 \%$.

The erosion rates at a wind speed of $18 \mathrm{~m} \mathrm{~s}^{-1}$ were estimated as $950 \mathrm{~g} \mathrm{~m}^{-2} \mathrm{~min}^{-1}$ for the sandy soil (particle size of $2 \mathrm{~mm}$ ), $175 \mathrm{~g} \mathrm{~m}^{-2} \mathrm{~min}^{-1}$ for the cultivated soil (particle size of $2 \mathrm{~mm}$ ), and $28 \mathrm{~g} \mathrm{~m}^{-2} \mathrm{~min}^{-1}$ for the cultivated soil (particle size of $10 \mathrm{~mm}$ ) (Zamani, Mahmoodabadi, 2013). Due to a very small mean weight diameter of the soil used in that study, the results shown in Figure 3 are lower than those of that study. Liu et al. (2006) measured the rates of soil wind erosion as 40.49 $\mathrm{g} \mathrm{m}^{-2} \mathrm{~min}^{-1}$ for the conventional flat tillage and as 16.70 $26.32 \mathrm{~g} \mathrm{~m}^{-2} \mathrm{~min}^{-1}$ for different ridge tillage applications at a wind velocity of $15 \mathrm{~m} \mathrm{~s}^{-1}$. The results of that study are similar to ours.

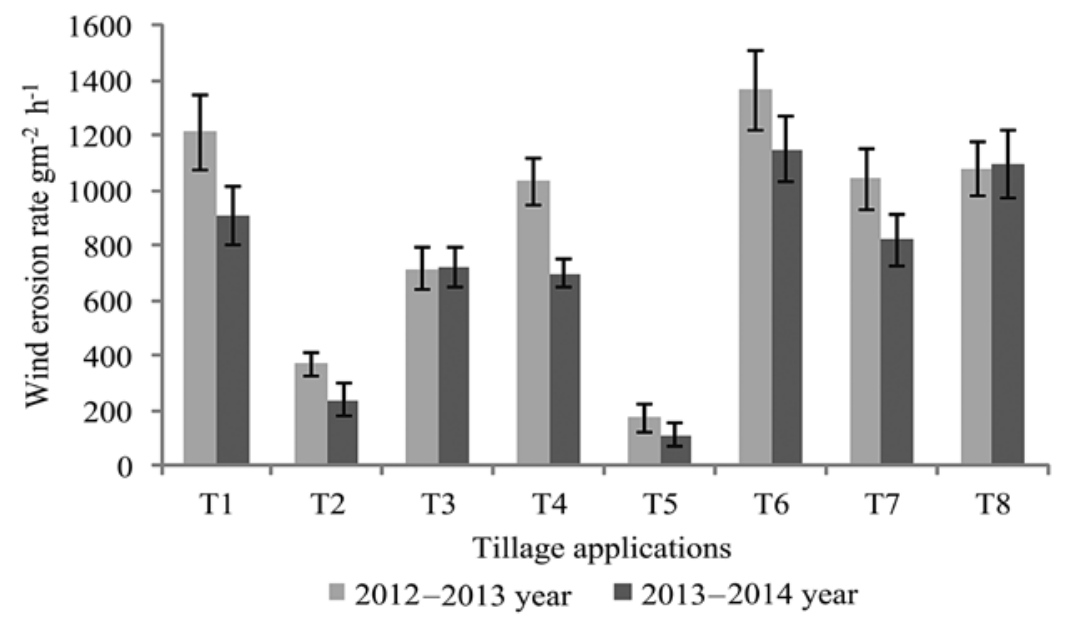

T1 - conventional tillage, T2 - chisel plough-float, T3 - winged chisel plough-float, T4 - alternative moving rototiller-float, T5 direct seeding, T6 - horizontal shaft rototiller (L-type foot)-float, T7 - horizontal shaft rototiller (I-type foot)-float, T8 - vertical shaft rototiller-float

Figure 3. The effect on wind erosion rate of different tillage applications

In the structure of the network developed, purelin was used in the first hidden layer, logsig in the second hidden layer, and the purelin transfer functions were used in the output layer. The lowest training error value for the network was obtained at the epoch number of 98 .

The mathematical formula of the ANN model is given as follows:

$$
y=\sum_{k=1}^{k}\left(W_{3}\right)_{k, m} * F_{k}+b_{k}
$$

The logsig transfer function for the second hidden layer $\left(F_{k}\right)$ is calculated as follows:

$$
F_{k}=\frac{2}{\left(1+e^{\left(-N E T_{k}\right)}\right)}
$$

where

$$
N E T_{k}=\sum_{j=1}^{j}\left(W_{2}\right)_{j, k} * F_{j}+b_{j}
$$

The purelin transfer function for the first hidden layer $\left(F_{j}\right)$ is calculated as follows: 


$$
F_{j}=N E T_{j}
$$

where

$$
N E T_{j}=\sum_{i=1}^{i}\left(W_{1}\right)_{i, j} * x_{1}+b_{1}
$$

In these equations, $i$ is the number of inputs, $j$ - the number of neurons in the first hidden layer, $k$ - the number of neurons in the second hidden layer, $m-$ the number of outputs, $W_{1}, W_{2}, W_{3}$ - the connection weights, $x$ - the input parameter, $y$ - the output parameter, and $b$ - the bias. The weights are provided in Tables 4,5 and 6 and the bias values are provided in Table 7.

Table 5. Weight values in the second hidden layer $\left(\mathrm{W}_{2}\right)$
Table 4. Weight values in the first hidden layer $\left(\mathrm{W}_{1}\right)$

\begin{tabular}{cc}
\hline $\begin{array}{c}\text { Number of neurons } \\
\text { in the first hidden layer }(\mathrm{j})\end{array}$ & $\left(\mathrm{W}_{1}\right)_{\mathrm{j}}$ \\
\hline 1 & -0.7301 \\
2 & 0.1673 \\
3 & 2.2643 \\
4 & 5.2386 \\
5 & 0.7518 \\
6 & -2.6571 \\
7 & -4.5441 \\
9 & 1.3613 \\
\hline
\end{tabular}

\begin{tabular}{ccccccccc}
\hline $\begin{array}{c}\text { Number of neurons } \\
\text { in the second } \\
\text { hidden layer }(\mathrm{k})\end{array}$ & $\left(\mathrm{W}_{2}\right)_{\mathrm{j} 1}$ & $\left(\mathrm{~W}_{2}\right)_{\mathrm{j} 2}$ & $\left(\mathrm{~W}_{2}\right)_{\mathrm{j} 3}$ & $\left(\mathrm{~W}_{2}\right)_{\mathrm{j} 4}$ & $\left(\mathrm{~W}_{2}\right)_{\mathrm{j} 5}$ & $\left(\mathrm{~W}_{2}\right)_{\mathrm{j} 6}$ & $\left(\mathrm{~W}_{2}\right)_{\mathrm{j} 7}$ & $\left(\mathrm{~W}_{2}\right)_{\mathrm{j} 8}$ \\
\hline 1 & 0.6284 & -0.9970 & 0.3865 & -1.4076 & 1.2607 & -0.7117 & -0.0349 & 0.4899 \\
2 & 1.7522 & 1.4121 & -0.1685 & 0.0024 & -1.0478 & 0.7708 & 0.1413 & 0.7466 \\
3 & 1.5759 & 2.1980 & 0.2593 & -2.1426 & 0.8146 & 1.9062 & 1.3993 & -1.2530 \\
4 & 2.0320 & 0.7446 & -1.1804 & -0.9528 & -1.2267 & -1.4492 & 0.8084 & -1.4166 \\
5 & -1.2456 & 0.7620 & 3.3860 & 6.1722 & 0.7107 & -1.9620 & -5.3003 & 1.3753 \\
\hline
\end{tabular}

Table 6. Connection weight values $\left(\mathrm{W}_{3}\right)$ for equation (6)

\begin{tabular}{cccccc}
\hline $\begin{array}{c}\text { Number } \\
\text { of outputs } \\
\mathrm{m}\end{array}$ & $\left(\mathrm{W}_{3}\right)_{\mathrm{k} 1}$ & $\left(\mathrm{~W}_{3}\right)_{\mathrm{k} 2}$ & $\left(\mathrm{~W}_{3}\right)_{\mathrm{k} 3}$ & $\left(\mathrm{~W}_{3}\right)_{\mathrm{k} 4}$ & $\left(\mathrm{~W}_{3}\right)_{\mathrm{k} 5}$ \\
\hline 1 & 0.5092 & -2.4732 & 3.7236 & -1.6915 & 2.8846 \\
\hline
\end{tabular}

Table 7. Bias values

\begin{tabular}{cccc}
\hline Number of neurons & $\mathrm{b}_{\mathrm{k}}$ & $\mathrm{b}_{\mathrm{j}}$ & $\mathrm{b}_{\mathrm{i}}$ \\
\hline 1 & -0.5527 & 3.8963 & 2.0175 \\
2 & & -1.4894 & -0.0894 \\
3 & & -0.0856 & -2.1649 \\
4 & & 2.2251 & -2.5731 \\
5 & & 2.8381 & 0.1522 \\
6 & & & -0.4374 \\
7 & & & 2.4753 \\
9 & & & -0.9755 \\
\hline
\end{tabular}

The results of the developed ANN were compared with the experimental results. For the testing data, the means of the measured and predicted values of the wind erosion rates were 701.20 and $706.68 \mathrm{~g} \mathrm{~m}^{-2} \mathrm{~h}^{-1}$, respectively. It was determined that the ANN model for which the number of neurons was 8 in the first hidden layer and the number of neurons was 5 in the second hidden layer provided the best results. In the ANN model, for test, the $R^{2}$ value was found to be $99.79 \%$ and the RMSE value, which was the lowest, was found to be 0.0253 ; for training, the $R^{2}$ value was found to be $99.75 \%$ and the RMSE value was found to be 0.032269 .

For the testing data, the mean relative error of the measured and predicted values (from the ANN model) was found to be $7.54 \%$. The relative error of the predicted value was found to be less $(10 \%)$ than the acceptable limits (Taner, 2007; Çarman, Taner, 2012). In the regression model, the $R^{2}$ value was found to be $92.64 \%$ and the RMSE value was found to be 0.0962 . The mean relative error of the wind erosion rate which was predicted by using the regression model was found to be $12.57 \%$. The mean relative errors in regression models were found to be greater than those for the ANN model.

The correlation between the measured and predicted values (from the ANN model) of the wind erosion rates in different tillage applications is shown in Figure 4. The determination coefficients of the relationship were found to be $99.37 \%$.

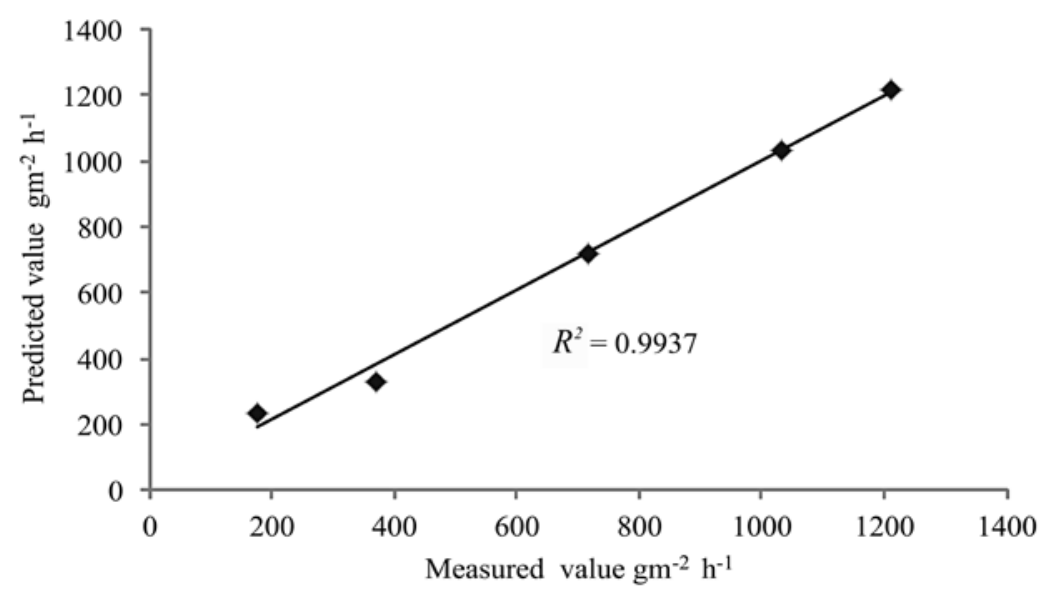

Figure 4. Correlation between measured and predicted values of the wind erosion rates 


\section{Conclusions}

In this study, measurements of the wind erosion rate in different tillage practices using a portable field wind tunnel were done and also a neural network was analyzed for the prediction of the wind erosion rate.

1. With increasing soil tillage intensity the dust concentration increased. The highest dust concentration was determined in horizontal shaft rototiller (L-type foot)-float (T6) application due to excess fragmentation of soil.

2. Intensive cultivation accelerates and exacerbates soil erosion so that conservation tillage is a major factor to reduce soil erosion. In this study, the lowest wind erosion rate was obtained in direct seeding application while the highest rate in horizontal shaft rototiller (L-type foot)-float (T6) application.

3. The overall results show that the networks can be used as an alternative method to find the wind erosion rate in these systems.

4. The Levenberg-Marquardt (LM), the gradient descent (GD) algorithm and the gradient descent algorithm with momentum (GDM) were studied, and the best results were obtained from the LM algorithm that used 13 neurons in the hidden layer. The mean values of the errors were found to be less than $8 \%$, and the maximum errors were found to be greater than $12 \%$. In addition to its numerical accuracy, the artificial neural network (ANN) model is much faster and easier to use, which makes it suitable for generating the wind erosion rate.

5. The developed model can be used as a reference for the forthcoming wind erosion studies. It can help farmers find an appropriate tillage application, in terms of sustainable agricultural techniques, in the arid regions where there is insufficient rainfall.

\section{Acknowledgements}

This project was supported by The Scientific and Technological Research Council of Turkey (TÜBİTAK, code 111 O 182).

Received 31032016

Accepted 26072016

\section{References}

Ağın O., Taner A. 2015. Determination of weed intensity in wheat production using image processing techniques. Anadolu Journal of Agricultural Sciences, 30: 110-117 http://dx.doi.org/10.7161/anajas.2015.30.2.110-117

Aimar S. B., Mendez M. J., Funk R., Buschiazzo D. E. 2012. Soil properties related to potential particulate matter emissions (PM10) of sandy soils. Aeolian Research, 3 (4): 437-443 http://dx.doi.org/10.1016/j.aeolia.2010.12.001

Basaran M., Erpul G., Uzun O., Gabriels D. 2011. Comparative efficiency testing for a newly designed cyclone type sediment trap for wind erosion measurements. Geomorphology, 130 (3-4): 343-351

http://dx.doi.org/10.1016/j.geomorph.2011.04.016

Blanco-Canqui H., Lal R. 2010. Principles of soil conservation and management, p. 109-133

http://dx.doi.org/10.1007/978-1-4020-8709-7 5
Çarman K., TanerA. 2012. Prediction of tire tractive performance by using artificial neural networks. Mathematical and Computational Applications, 17 (3): 182-192 http://dx.doi.org/10.3390/mca17030182

Ekinci S., Çarman K., Kahramanli H. 2015. Investigation and modeling of the tractive performance of radial tires using off-road vehicles. Energy, 93: 1953-1963 http://dx.doi.org/10.1016/j.energy.2015.10.070

Kashaninejad M., Dehghani A. A., Kashiri M. 2009. Modeling of wheat soaking using two artificial neural networks (MLP and RBF). Journal of Food Engineering, 91: 602-607 http://dx.doi.org/10.1016/j.jfoodeng.2008.10.012

Labiadh M., Bergametti G., Kardous M., Perrier S., Grand N., Attoui B., Sekrafi S., Marticorena B. 2013. Soil erosion by wind over tilled surfaces in South Tunisia. Geoderma, 202 (3): $8-17$

http://dx.doi.org/10.1016/j.geoderma.2013.03.007

Liu M., Wang J., Yan P., Liu L., Ge Y., Li X., Hu X., Song Y., Wang L. 2006. Wind tunnel simulation of ridge-tillage effects on soil erosion from cropland. Soil and Tillage Research, 90: 242-249 http://dx.doi.org/10.1016/j.still.2005.10.005

Logsdon S. D. 2013. Depth dependence of chisel plow tillage erosion. Soil and Tillage Research, 128: 119-124 http://dx.doi.org/10.1016/j.still.2012.06.014

Lopez M. V., Gracia R., Arrue J. L. 2000. Effects of reduced tillage on soil surface properties affecting wind erosion in semiarid fallow lands of Central Aragon. European Journal of Agronomy, 12: 191-199 http://dx.doi.org/10.1016/S1161-0301(00)00046-0

Martí P., Gasque M., Gonzalez-Altozano P. 2013. An artificial neural network approach to the estimation of stem water potential from frequency domain reflectometry soil moisture measurements and meteorological data. Computers and Electronics in Agriculture, 91: 75-86 http://dx.doi.org/10.1016/j.compag.2012.12.001

Maurer T., Herrmann L., Gaiser T., Mounkaila M., Stahr K. 2006. A mobile wind tunnel for wind erosion field measurements. Journal of Arid Environments, 66: 257-271 http://dx.doi.org/10.1016/j.jaridenv.2005.11.002

Meijer A. D., Heitman J. L., White J. G., Austin R. E. 2013. Measuring erosion in long-term tillage plots using groundbased lidar. Soil and Tillage Research, 126: 1-10 http://dx.doi.org/10.1016/j.still.2012.07.002

Mendez M. J., Buschiazzo D. E. 2010. Wind erosion risk in agricultural soils under different tillage systems in the semiarid Pampas of Argentina. Soil and Tillage Research, 106: $311-316$ http://dx.doi.org/10.1016/j.still.2009.10.010

Naghsh-Nilchi R., Aghashahi M. 2009. Classification of epileptic states using rootmusic and MLPNN. Proceedings of the $17^{\text {th }}$ European signal processing conference. Scotland, p. 2377-2381

Samarasinghe S. 2007. Neural networks for applied sciences and engineering: from fundamentals to complex pattern recognition. Boca Raton, USA

Sharratt B., Feng G. 2009. Windblown dust influenced by conventional and undercutter tillage within the Columbia Plateau, USA. Earth Surface Processes and Landforms, 34: 1323-1332 http://dx.doi.org/10.1002/esp.1812

Sharratt B., Wendling L., Feng G. 2010. Windblown dust affected by tillage intensity during summer fallow. Aeolian Research, 2: 129-134 http://dx.doi.org/10.1016/j.aeolia.2010.03.003 
Singh P., Sharratt B., Schillinger W. F. 2012. Wind erosion and PM10 emission affected by tillage systems in the world's driest rainfed wheat region. Soil and Tillage Research, 124: 219-225

http://dx.doi.org/10.1016/j.still.2012.06.009

Taner A. 2007. Design of radial centrifugal pumps using artificial neural network: doctoral thesis. Graduate School of Natural and Applied Sciences of Selçuk University, Konya, Turkey (in Turkish)
Wang J., Miller D. R., Sammis T. W., Hiscox A. L., Yang W., Holmén B. A. 2010. Local dust emission factors for agricultural tilling operations. Soil Science, 175 (4): 194-200 http://dx.doi.org/10.1097/SS.0b013e3181dae283

Zamani S., Mahmoodabadi M. 2013. Effect of particlesize distribution on wind erosion rate and soil erodibility. Archives of Agronomy and Soil Science, 59 (12): 1743-1753

http://dx.doi.org/10.1080/03650340.2012.748984

ISSN 1392-3196 / e-ISSN 2335-8947

Zemdirbyste-Agriculture, vol. 103, No. 3 (2016), p. 327-334

DOI $10.13080 /$ z-a.2016.103.042

\title{
Vèjo erozijos matavimai ir modeliavimas ịvairiose žemės dirbimo sistemose, naudojant vèjo erozijos tunelị
}

\author{
K. Çarman ${ }^{1}$, T. Marakoğlu ${ }^{1}$, A. Taner ${ }^{2}$, F. Mikailsoy ${ }^{3}$ \\ ${ }^{1}$ Selcuk universitetas, Turkija \\ ${ }^{2}$ Ondokuz Mayss universitetas, Turkija \\ ${ }^{3}$ Iğdır universitetas, Turkija
}

\section{Santrauka}

Dirbtinio intelekto sistema yra plačiai pripažinta kaip technologija, teikianti alternatyvų sudètingų problemų sprendimo būdą. Dirbtinių neuronų tinklas yra metodas, turintis lanksčią matematinę struktūrą, padedantis nustatyti sudètingą netiesinį ryšį tarp įvesties ir išvesties duomenų. Tyrimo tikslas - nustatyti ryšį tarp dulkių koncentracijos bei vèjo erozijos dydžio ir pademonstruoti, kaip dirbtinių neuronų tinklas galètų padèti prognozuojant vèjo erozijos dydị. Duomenys gauti lauko eksperimentų metu naudojant portatyvų vèjo tunelį. Tïrti 8 žemès dirbimo būdai: tradicinis, 6 minimalaus dirbimo ir tiesioginè sejja. Kietujų dalelių (KD) koncentracija sumažejo mažejant žemès dirbimų skaičiui ir intensyvumui. Mažiausia kietujų dalelių koncentracija $\left(\mathrm{KD}_{10}\right)$ buvo nustatyta taikant tiesioginę sèją. Po žemès dirbimų taikymo vėjo erozija svyravo tarp 113 ir $1365 \mathrm{~g} \mathrm{~m}^{-2} \mathrm{~h}^{-1}$.

Tyrimo rezultatai parodè, kad vejjo erozijos dydis buvo mažesnis tiesioginės sejjos laukeliuose, palyginus su tradiciniu ir minimaliu žemės dirbimu. Straipsnyje aptariamas intelektinis modelis, skirtas prognozuoti vėjo erozijos dydžio pokyčius, atsirandančius dèl žemės dirbimo metu susidarančios dulkių koncentracijos. Be to, modelis taikytas naudojant tradicinius vejjo erozijos dydžio vertinimo metodus ir kompiuterinès programos Statistica 5-ąą versiją. Dirbtinių neuronų tinklas pateikè tikslesnes prognozes, palyginus su netiesine regresija. Prognozuotų verčių santykinė paklaida buvo gauta mažesnè nei priimtinas lygis (10\%). Remiantis šio tyrimo rezultatais, dirbtinių neuronų tinklas yra perspektyvus metodas vejo erozijos dydžiui prognozuoti.

Reikšminiai žodžiai: dirbtinių neuronų tinklas, dirvožemio vejjo erozija dulkių koncentracija, tausojamasis žemès dirbimas.

Please use the following format when citing the article:

Carman K., Marakoglu T., Taner A., Mikailsoy F. Measurements and modelling of wind erosion rate in different tillage practices using a portable wind erosion tunnel. Zemdirbyste-Agriculture, 103 (3): 327-334 DOI 10.13080/ z-a.2016.103.042 